\title{
Middle School Students' Learning Difficulties in the Ratio-proportion Topic and a Suggested Solution: Envelope Technique
}

\author{
Hamza Çalışııı \\ Faculty of Education, Ondokuz Mayıs University, Turkey
}

Copyright $(2018$ by authors, all rights reserved. Authors agree that this article remains permanently open access under the terms of the Creative Commons Attribution License 4.0 International License

\begin{abstract}
Ratio-proportion is one of the topics that middle school students have difficulty in comprehending. This study aims to determine the learning difficulties that seventh-grade students face while learning about ratio-proportion. Three commonly used strategies to solve ratio-proportion problems are buildup, unit ratio and cross-multiplication. The study also investigated the effect of the envelope technique, which included these three strategies and was developed to improve comprehending and success of students. The study was designed as an experimental study and 34 seventh-grade students participated in the study. The Ratio-Proportion Achievement Test developed by the researcher used to collect the data. The results illustrated that students frequently have misconceptions while solving ratio-proportion problems by confusing the direction of the operation in reducing and expanding the numbers constituting the proportion. It was concluded that the envelope technique is a method that assists students in reaching a rapid, correct solution in ratio-proportion problems, subsequently increasing their mathematical achievements.
\end{abstract}

Keywords Ratio-proportion, Expanding Fractions, Reducing Fractions, Misconception, Envelope Technique

\section{Introduction}

Mathematics is a core subject facilitating the understanding of sciences. However, the acquisition of abstract concepts is more difficult in mathematics compared to other courses. This stems from the fact that mathematics is a field where the abstract and prerequisite relationship is intense by its nature [1]. When a topic is not completely comprehended in mathematics, learning difficulties progress, hampering understanding of other mathematics topics cause students to make further mistakes. Consequently, the process of learning gradually becomes more difficult and as a result, students emerge with decreasing math achievement and high anxiety levels.

Mathematics education targets the success of all students; however, some students succeed in mathematics without difficulty while others struggle finding mathematics more difficult [2]. Students' achievement in mathematics depends on their mastery and ability to transfer their prior math knowledge. Studies detected different factors leading to students' learning difficulties in mathematics: cognitive reasoning, learning methods, students' attitudes and perceptions, and problems stemming from the environmental change with the transition from high school to the university [3]. Although different terms such as "difficulty" or "mistake" are used to identify problems encountered in mathematics teaching, the term "misconception" better refers to the students' learning difficulties [4]. Students' prior knowledge should be determined in order to change their misconceptions regarding a mathematical concept and mathematics teaching should be restructured according to students' learning abilities. If students are not provided with necessary feedback after detecting their misconceptions; then, these misconceptions might not manifest itself within the system. Students will be unable to correct their misconceptions [5], which negatively influences their future math successes.

Fractions are one of the mathematics topics that students and teachers find difficult. One of the main reasons for students' difficulties in fractions is that they memorize the formulas and algorithm instead of understanding fractions. The other reason is that they perceive the numerator and denominator of fractions as two different integers [6]. Related studies in the literature found that students and teachers have misconceptions about this topic [7-11]. Monteiro [10] determined that primary mathematics teachers experience difficulties in the ratio-proportion 
concept while solving problems, which stems from their misconceptions during their middle and high school education. Brown and Quinn [8] applied a test consisting of six categories to determine the fluency of 143 high school students in the basic concepts and calculations in rational numbers. It was determined that $48 \%$ of the students were unable to provide a correct answer to the problem on the multiplication process in fractions. Furthermore, these students do not know the standard multiplication algorithm including reducing before multiplication. Zengin [11] investigated seventh-grade students' mistakes and misconceptions in the fractions topic and found the student have misconceptions in understanding of fractions, doing fraction exercises, expressing the relationship of fraction with other sets of numbers, ordering fractions, determining the steps in problems where the steps are given in a mixed order, and whole numbers. Students as well as teachers have difficulties with fractions topics [12]. Preservice teachers may also not be aware of students' misconceptions about fractions topic [13].

Learning the ratio and proportion concepts in fractions topics constitutes the base for learning important concepts such as percentages, equations, worker and pool problems, and velocity problems. Therefore, it is of critical importance to thoroughly learn the ratio-proportion topic and to detect misconceptions in this topic [9]. Students were found to frequently use the cross-multiplication method to solve the ratio-proportion problems stated in textbooks [14]. However, issues surface such as not understanding the problem, the inability to transform verbal problems into the mathematical language, and the inability to establish an appropriate equation about the verbal problem given. An additional issue is the inability to simplify the equation because of the mistakes made after the stage of forming the equation. This is encountered in the shift from arithmetic to algebra in the transition from middle to high school [15]. Highlighting the importance of the ratio concept in the development of proportional reasoning, Karagöz Akar [16] listed students' misconceptions in the ratio concept as misconceptions about additive and multiplicative association, misconceptions about covariation and transformation, and misconceptions about constancy. Other studies in the related literature corroborate the results that students and teachers have problems in the topics of ratio-proportion and reducing fractions $[4,9,17-20]$. For example, in a related study, middle school students were found to have misconceptions about reducing and expanding fractions in a mathematics education delivered with scenario-based problems. The following question was presented to students, "The value of a fraction does not change when its numerator or denominator are multiplied or divided by the same number. What if the same number is added to the numerator and denominator; Does the value of the fraction change?" When their answers were investigated, only three students were able to provide a correct answer. Singh [20] investigated how two sixth-grade students construct the ratio-proportion concepts in their minds and determined that two mental processes are combined and iterated. This emphasizes the significant role of processes in comprehending the ratio topic. Consequently, teaching the ratio as a holistic ratio strategy in a standardized approach is not helpful in developing students' multiplicative reasoning skills. Studies also asserted that many students experience serious difficulties in simplifying algebraic expressions [21]. Studies were also conducted to examine the effect of different methods on students' skills in solving problems on the ratio-proportion topic. In these studies, for example, it was found that schema-based education increases students' abilities [22]. Charalambous and Pitta-Pantazi [23] investigated the relationships between the part-whole and other meanings of the fraction and modeled the relationships between the part-whole and other four meanings (ratio, processor, division, measurement) using the path diagram. In conclusion, the part-whole, in particular, explained $98 \%$ of the variance of the factors related to the ratio and processor characters of the fractions.

Ratio-proportion problems can be solved using a broad range of strategies. Buildup strategy, unit ratio strategy and cross-multiplication are three of the most widely used strategies [24]. In buildup strategy, the numbers within one ratio are repeatedly added to solve the problem (e. g. to solve $\frac{3}{4}=\frac{x}{12}$ it is added $\frac{3}{4}$ three times until the result of $\frac{9}{12}$ is reached, and then it is seen that $x$ is equal to 9). An integral relation between the components numbers in the two ratios facilitate the use of the buildup strategy - a relation in which the numbers in one ratio can be generated by repeatedly adding numbers in the other ratio. For example, the ratios $\frac{3}{4}$ and $\frac{9}{12}$ have an integral relation because repeatedly adding $3 \mathrm{~s}$ and $4 \mathrm{~s}$ to the first ratio leads to second ratio. Some problems don't involve an integral relation (e.g. $\frac{3}{9}=\frac{x}{6}$ ). Such problems can be solved with another strategy called unit ratio strategy. In this strategy, the known ratio $\frac{3}{9}$ is reduced to a form with a numerator of 1 and then multiplicative relation between the new unit ratio and the ratio with the unknown element $\frac{x}{6}$ is determined. For example, in the equation $\frac{3}{9}=\frac{x}{6}$, the ratio $\frac{3}{9}$ is equal to the unit ratio $\frac{1}{3}$. Then it can be written $\frac{1}{3}=\frac{x}{6}$. Multiplied $\frac{1}{3}$ by $\frac{2}{2}$, the common denominator 6 is found. Hence the numerators of the equal fractions $\frac{2}{6}=\frac{x}{6}$ must be equal, that is, $x=2$. In the equivalence of two 
fractions, the version that is reduced to its minimum term might not always be a unit fraction (e.g., $\frac{6}{15}=\frac{x}{10}$, in which reducing $\frac{6}{15}$ results in $\frac{2}{5}$ ). Unit ratio strategy can also be generalized to such situations [24].

The buildup and unit ratio strategies are basically concerned with reducing and expanding the equivalent fractions constituting the proportions. According to this, in a $\frac{a}{b}=\frac{c}{d}$ proportion, the numerator and denominator of each fraction can be divided and multiplied by the same number. In addition, when the numerators $(a$ and $c$ ) of the fractions in the $\frac{a}{b}=\frac{c}{d}$ proportion are multiplied or divided by the same number, the equation is protected. The same situation holds true for the denominators ( $b$ and $d$ ) of the fractions. Thus, the following model is obtained.

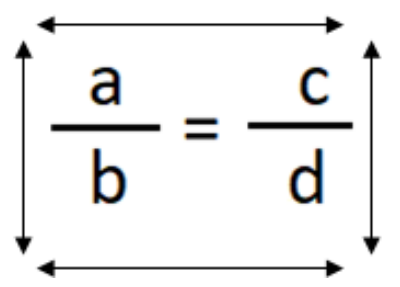

Figure 1. Arrows displaying number pairs that can be multiplied or divided by the same number

The two-directional arrows given in the model in Figure 1 indicates which number pairs can be multiplied or divided by a number in a way that protects the equation (e.g., if $\frac{21}{30}=\frac{x}{35}$, then in the $\mid \frac{21}{30}=\frac{x}{35}$ equation, when 21 and 30 number pair is divided by 3 in the direction of the vertical line, $\frac{7}{10}=\frac{x}{35}$ is obtained. Now, in the $\frac{7}{10}=\frac{x}{35}$ equation, when 10 and 35 number pair is divided by 5 in the direction of the horizontal line, $\frac{7}{2}=\frac{x}{7}$ is obtained).

Cross-multiplication is another strategy used to solve ratio-proportion problems. Teachers can first present problems that can be solved using the buildup and unit ratio strategies; thereafter, they can continue with the problems that can be more easily solved using the cross-multiplication strategy [24]. When the terms of a proportion are cross multiplied, it is known that the cross products are equal, that is, if $\frac{a}{b}=\frac{c}{d}$ then $a \cdot d=b \cdot c \cdot$ Cross multiplication is generally demonstrated with the following model:

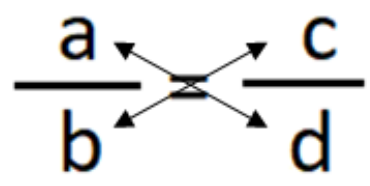

Figure 2. Cross-multiplication

Thus, the below model is formed through the combination of the models presented in Figures 1 and 2.

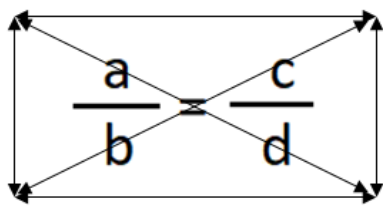

Figure 3. Envelope Technique Model

The envelope technique model formed with the combination of the rectangle in Figure 1 and the cross in Figure 2 is seen in Figure 3. According to this model which is called Envelope Technique since it looks like an envelope, students cross multiply the number pairs in the direction of the diagonal line of the envelope in an equation of two fractions. They can multiply or divide the number pairs in the direction of sidelines of the envelope with a number.

With the envelope technique, the aim is to prevent misconceptions students make while solving ratio-proportion problems and to provide them a means to the solution in a fast, accurate way. Consequently, this study will address the following issues:

1. What are the misconceptions middle school students have while solving ratio-proportion problems?

2. What is the effect of the envelope technique on the students' abilities in the ratio-proportion topic?

\section{Method}

The experimental design was used in the study. The experimental design is an application where dependent and independent variables are defined, thus the experiment can be carried out with randomization under statistical conditions. The primary focus of an experimental study is to establish a causative relationship between the dependent and independent variables [25]. Experimental studies identify relationships, move beyond predictions, and make a partial determination regarding the causes of what happens [26]. 


\subsection{Design of the Study}

One group pretest-posttest experimental design was used in the study. There is an implementation group in this design. The group is evaluated or observed not only after but also before the implementation [26]. This design enables the researcher to compare the means of the pretest and posttest scores which are measured with same sensitivity. In this approach, the independent variable should be related to the dependent variable [25]. In this study, the misconceptions that the students make in the ratio-proportion topic were primarily determined and an experimental implementation was carried out using the envelope technique. The effect of the technique on the students' achievement was investigated taking measurements before and after the implementation.

\subsection{Participants}

The study was conducted in a public school in the Black Sea region of Turkey during the 2016-2017 academic year. Using the random sampling technique, 34 seventh-grade students (12 females, 22 males) were selected as participants of the study. The school has a medium socioeconomic status. The fact that the school displays a moderate success in the central exams indicates a rigorous school sufficient to represent the sample. The students' math achievement scores were obtained from the school administration and found to be moderate. The descriptive statistics regarding the students' math achievement scores are presented in Table 1.

Table 1. Descriptive statistics regarding the participants

\begin{tabular}{|c|c|c|c|c|}
\hline & & f & $\%$ & Total \\
\hline \multirow{2}{*}{ Gender } & Female & 22 & 65 & \multirow{2}{*}{34} \\
\hline & Male & 12 & 35 & \\
\hline \multirow{5}{*}{ Math scores } & Between 0-45 & 5 & 14 & \multirow{5}{*}{34} \\
\hline & Between 46-55 & 6 & 18 & \\
\hline & Between 56-70 & 7 & 21 & \\
\hline & Between 71-85 & 9 & 26 & \\
\hline & Between 86-100 & 7 & 21 & \\
\hline
\end{tabular}

\subsection{Data Collection Tools}

The Ratio-Proportion Achievement Test developed by the researcher was used to collect the data in the study. The Middle School Mathematics Curriculum [27], mathematics textbook and the related literature were reviewed in the development of the test. A question pool regarding the ratio-proportion topic was formed. Experts' opinions were consulted regarding the questions prepared and five open-ended questions were included in the test. In addition, five true-false questions were included in the test in order to detect the students' errors in this topic. A pilot implementation was carried out and the test was finalized based on the pilot results. A significant high-level relationship was found between the students' scores on the pretest and their math achievement scores in the term (Pearson correlation. 743, $\mathrm{p}<.05$. For this reason, the test developed was considered as a reliable instrument to measure the students' achievement in the ratio-proportion topic.

\subsection{Analyzing Data}

A rubric was created for the open-ended questions in the achievement test and the students' answers were graded accordingly. A complete and correct answer was graded as two points, a partially correct answer was graded as one point, and an incorrect answer or blank was graded as zero points. In the true-false section, a correct answer was one point, while an incorrect answer was zero points. Obtainable scores on the scale ranged between zero and 15 points. This grading was used to score the students' pretest and posttest. The students' pretest and posttest scores displayed a normal distribution; therefore, their scores were compared using the paired samples t-test; a parametric test.

The students' answers to the open-ended questions in the pretest were subjected to an in-depth analysis and their misconceptions were determined. These misconceptions were stated with the examples in the results section. After the envelope technique was presented, the students' answers to the open-ended questions in the posttest were also subjected to an in-depth analysis. Finally, the effect of the envelope technique on the students' achievement scores in the ratio-proportion topic was presented with the examples in the results section.

\subsection{Implementations}

The implementation was carried out in a math lesson and the students studied in groups in accordance with cooperative learning. The students' active participation in the process was monitored carefully. Within the scope of the study, these stages were followed:

1. Administering the Ratio-Proportion Achievement Test to the students as the pretest.

2. Having a brainstorming session to determine the students' prior knowledge level and areas of inadequate learning and solving example questions.

3. Separating the students into cooperative learning groups and preparing the envelope models using card boards.

4. Teaching the envelope technique using the prepared envelope models.

5. Presenting a creative drama to enhance the comprehension of the envelope technique.

6. Solving the worksheets on this topic using the envelope technique.

7. Administering the posttests. 


\section{Findings}

The learning difficulties that the middle school students experience in the ratio-proportion topic were determined by analyzing the students' answers to the open-ended questions in the achievement test. When the students' methods of solutions were analyzed, many students were found to have misconceptions while solving ratio-proportion problems; therefore, they were unable to ascertain the correct answer. For example, the mistake that one student (S17) made is illustrated in Figure 4.

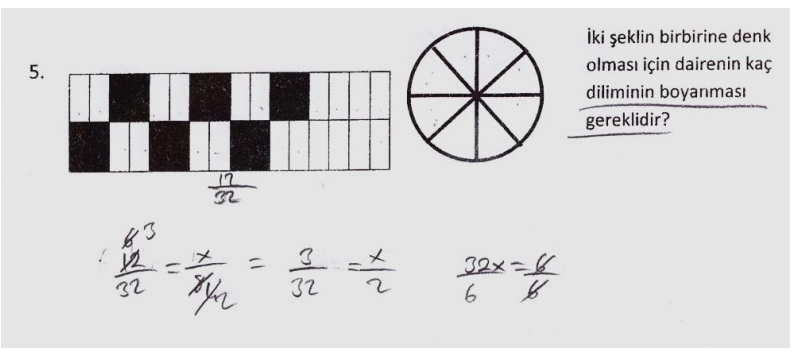

Figure 4. S17' answer in the pretest

In the question presented in Figure 4, the students were asked how many slices in the circle should be shaded in order for the proportions of the shaded areas to be equivalent to each other. The students established a correct equivalence between the ratios that different figures point out $\left(\frac{12}{32}=\frac{x}{8}\right)$. However, since they made the reduction between the incorrect number pairs, they were unable to reach the correct solution $\left(\frac{32 x}{6}=\frac{6}{6}\right)$. This indicates that the students do not understand which number pairs among the four number pairs in the numerator and denominator to reduce.

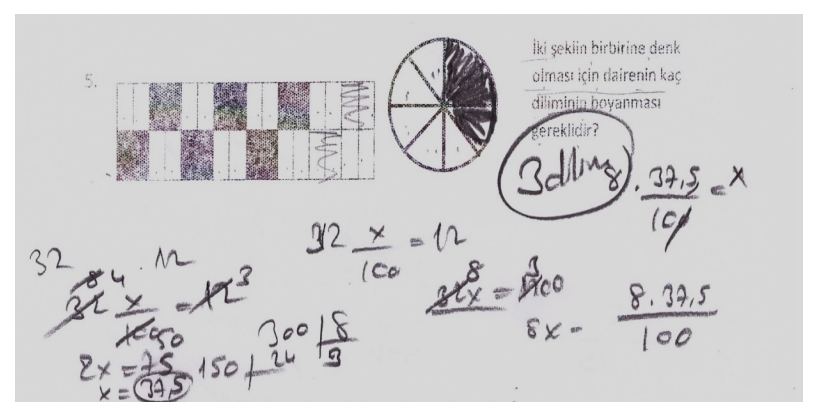

Figure 5. S15' answer in the pretest

Another student's answer to the same question can be seen in Figure 5. Here, the student directly calculated the percentage of the shaded area in the left figure, instead of establishing a direct proportion. Later, he or she correctly calculated how many slices of the second figure should be shared with the help of this percentage. However, this obviously extended the solution time of the problem and increases the likelihood of an arithmetic error because it contains many steps.

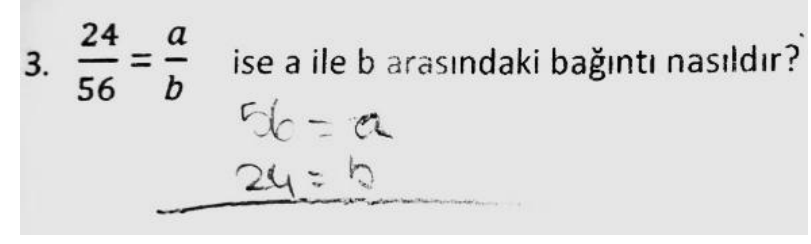

Figure 6. S23's answer in the pretest

In the question presented in Figure 6, the students were asked the relationship between a and $\mathrm{b}$. The student directly said that a is 24 and b is 56 . This situation shows that some students perceive the numerator and denominator of fractions as two different integers.

$$
\begin{aligned}
& \text { 2. } \frac{16}{27}=\frac{32}{A} \quad \text { denkliğinde A'nın değeri nedir? } \\
& 32-16=16 \\
& A=\frac{43}{7} \\
& 27+16=43
\end{aligned}
$$

Figure 7. S32's answer in the pretest

In the research, it was seen that some students think that the value of a fraction does not change when the same number is added to its numerator or denominator. For example the misconception that one student (S. 32) made is illustrated in Figure 7. To find the value A, the student first found the difference between 32 and 16 numbers. He then thought that the right-hand denominator had been obtained by adding this difference to the left-hand denominator.

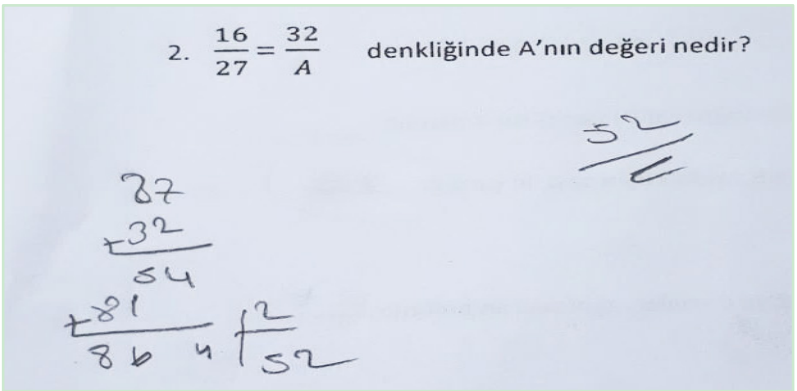

Figure 8. S8's answer in the pretest

As seen in Figure 8, the student started with the cross-multiplication and tried to reach the solution by dividing again following a multiplication. The student did not reduce at the beginning; therefore, he or she made the solution with large numbers, which caused arithmetic errors. Therefore, the student was unable to reach the correct answer.

The students' answers in the true-false section of the achievement test indicated that some of the students do not 
know or confuse which number pairs of the proportion can be multiplied or divided with the same number without altering the equation. In their answers to the open-ended questions, on the other hand, it was determined that they make mistakes while reducing a fraction or they make multiplication without reducing; therefore, they were unable to reach the correct answer.

In order to determine the effect of the implementation on the students' achievement levels, their pretest and posttest scores were compared using paired samples t-test and the results were presented in Table 2 .

Table 2. Comparing the students' pretest and posttest scores-Paired samples t-test results

\begin{tabular}{|c|c|c|c|c|c|c|}
\hline Measurement & $\mathbf{N}$ & $\overline{\boldsymbol{X}}$ & $\mathbf{s d}$ & $\mathbf{d f}$ & $\mathbf{t}$ & $\mathbf{p}$ \\
\hline Pretest & 34 & 7.91 & 3.72 & \multirow{2}{*}{33} & \multirow{2}{*}{7.830} & \multirow{2}{*}{$.000^{*}$} \\
\hline Posttest & 34 & 11.26 & 2.75 & & & \\
\hline
\end{tabular}

$* \mathrm{p}<.05$

As Table 2 shows, a significant difference was found between the students' scores before and after the implementation $(\mathrm{t}=5.004, \mathrm{p}<.05)$. While the mean of the students' scores was $\overline{\boldsymbol{X}}=11.61$ before the implementation, this mean increased to $\bar{X}=14.97$ after the implementation carried out with the envelope technique. These results pointed out that the envelope technique is an effective method to increase the students' mathematical competency. In addition, when the students were asked to solve the same questions using the envelope technique, it was determined that they solved a higher number of questions correctly and made fewer mistakes. For example, Figure 9 shows how a student solved the problem on the equivalent fraction using the envelope technique.

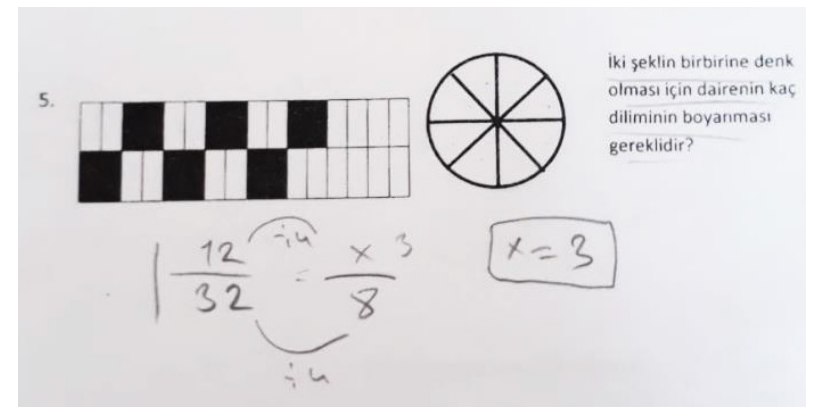

Figure 9. S13's answer in the posttest

Another student's (S13) answer to the proportion problem using the envelope technique can be seen in Figure 7. The student first established a correct equivalence between the ratios indicated by different figures $\left(\frac{12}{32}=\frac{x}{8}\right)$. Then he or she directly reached the solution by dividing by 4 the number pair in the direction of the sideline on the left side of the envelope. This process that the student made as a result of the envelope technique involves the unit ratio strategy.

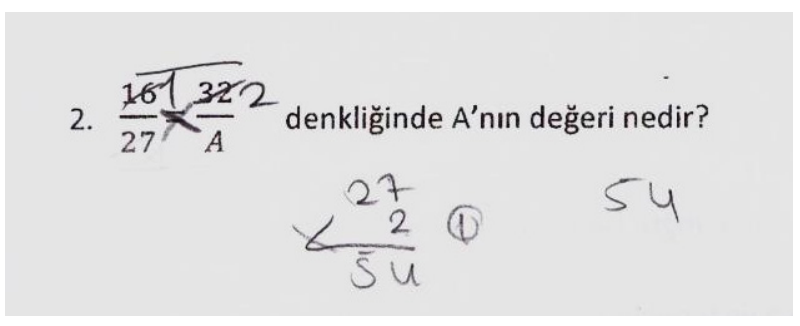

Figure 10. S25's answer in the posttest

As seen in Figure 10, the student was able to solve the equivalent fraction problem using the envelope technique. The student first reduced the number pairs in the direction of the upper sideline of the envelope and reached the correct solution rapidly by multiplying the number pairs in the direction of the crosslines of the envelope; that is to say, with cross-multiplication.

\section{Discussion}

The ratio-proportion in fractions is one of the most basic topics of mathematics. Students' lack of aptitude in this topic could influence their entire mathematics competencies. This study primarily aimed to determine the students' misconceptions while solving the problems on the ratio-proportion topic. Later, the envelope technique involving the buildup, unit ratio and cross-multiplication strategies were taught in order to enable students to reach the correct solution in a more efficient way and the effect of this technique was measured.

The results of the study revealed that the students experience learning difficulties in the ratio-proportion topic. It was particularly noted in the study that students lack comprehension regarding which number pairs of the proportion can be multiplied or divided with the same number without altering the equation. This research showed that some students perceive the numerator and denominator of fractions as two different integers. In addition, it has been found that students have a misconception that if the same number is added to a fraction's nominator and denominator, the value of a fraction does not change. It was also concluded that making cross-multiplication without reducing caused the students to make arithmetic errors. Different studies in the literature illustrate that other students have similar problems $[6,11$, 15, 17 and 21]. Doğan and Çetin [28] in their study determined seventh- and ninth-grade students' misconceptions in the ratio-proportion topic and found that the students lacked knowledge regarding the definitions of ratio and proportion, had misconceptions about the features of the proportion, and confused the ratio with fraction number and the division operation. However, the t-test result comparing the pretest and posttest scores in this study demonstrates the effect of the envelope technique. The considerable increase in the students' number of correct answers in the true-false section in the posttest and 
their ability to correctly solve the open-ended questions in a rapid way using the envelope technique indicated the positive effect of the technique.

The envelope technique is an effective method that can be used when teaching rational numbers and ratio-proportion topics to middle school students. Using the envelope technique is thought to prevent some of the students' learning difficulties and to help them fully comprehend the topic. The envelope technique, as a catchy model, can be included in middle school textbooks and the teachers can utilize this technique when presenting these topics.

\section{REFERENCES}

[1] Y. Baykul. İlköğretimde Matematik Öğretimi (1-5. Sinıflar). Ankara: Pegema Yayıncılık, 1999.

[2] D. O. Tall \& M. R. Razali. Diagnosing students' difficulties in learning mathematics, International Journal of Mathematical Education in Science and Technology, 24(2), 209-222, 1993.

[3] M. Y. Yudariah \& A. R. Roselainy. Matematics education at university teknologi Malaysia (UTM): Learning from experience, Jurnal Teknologi 34(E), 9-24, 2001.

[4] E. Bingölbali \& M. F. Özmantar. İlköğretimde Karşılaşılan Matematiksel Zorluklar ve Çözüm Önerileri, Ankara, Pegem Akademi, 2010.

[5] A. Baki. Kuram ve Uygulamada Matematik Eğitimi [Mathematics Education in Theory and Practice], Ankara, Harf yayınları, 2008.

[6] İ. Şiap \& A. Duru. Kesirlerde geometriksel modelleri kullanabilme becerisi, Gazi Üniversitesi Kastamonu Eğitim Dergisi, 12(1), 89-96, 2004.

[7] C. Alacaci. "Öğrencilerin Kesirler Konusundaki Kavram Yanılgıları", In Bingölbali, E. \& Özmantar M.F. (Eds.), İlköğretimde Karşılaşılan Matematiksel Zorluklar ve Çözüm Önerileri (ss. 63-95), Ankara, Pegem Akademi, 2009.

[8] G. Brown \& R. J. Quinn. Algebra students' difficulty with fractions: An error analysis, Australian Mathematics Teacher, 62(4), 28-40, 2006.

[9] A. Kaplan, T. İşleyen \& M. Öztürk. 6. Sınıf oran orant1 konusundaki kavram yanılgıları, Kastamonu Eğitim Dergisi, 19(3), 953-968, 2011.

[10] C. Monteiro. Prospective elementary teachers' misunderstandings in solving ratio and proportion problems, International Group for the Psychology of Mathematics Education, 3, 317-324, 2003.

[11] S. Zengin. Rasyonel Sayıların Öğretiminde Karşıllaşılan Kavram Yanılgıları ve Hataların Tespiti. Yayınlanmamış Yüksek Lisans Tezi, Atatürk Üniversitesi, Eğitim Bilimleri Enstitüsü, 2014.

[12] M. F. Özmantar \& E. Bingölbali. Sınıf öğretmenleri ve matematiksel zorlukları, Gaziantep University Journal of Social Sciences, 8(2), 401-427, 2009.

[13] D. Tirosh. Enhancing prospective teachers' knowledge of children's conceptions: The case of division of fractions, Journal for Research in Mathematics Education, 31(1), 5-25, 2000.

[14] O. Akkuş Ç1kla\& A. Duatepe. İlköğretim matematik öğretmen adaylarının orantısal akıl yürütme becerileri üzerine niteliksel bir çalışma, Hacettepe Üniversitesi Eğitim Fakültesi Dergisi, 23, 32-40, 2002.

[15] R. Gürbüz \& Z. Toprak. Designation, implementation and evaluation of activities to ensure transition from arithmetic to algebra, Necatibey Faculty of Education Electronic Journal of Science \& Mathematics Education, 8(1), 178-203, 2014.

[16] G. Karagöz Akar. Oran Konusunun Kavramsal Öğreniminde Karşılaşılan Zorluklar ve Çözüm Önerileri. In M. F. Özmantar, E. Bingölbali (Eds.) İlköğretimde Karşılaşılan Matematiksel Zorluklar ve Çözüm Önerileri, Ankara, Pegem Akademi, 2010.

[17] E. Atasoy \& Ş. Atasoy. Farklı yazma etkinliklerinin 6. Sınıf öğrencilerinin düşünceleri ve davranışları üzerindeki etkilerinin belirlenmesi, Hasan Ali Yücel Eğitim Fakültesi Dergisi, 3(1), 1-18, 2006.

[18] R. Ekawati, F. Lin \& K. Yang. The Enactment of Mathematics Content Knowledge and Mathematics Pedagogical Content Knowledge in Teaching Practice of Ratio and Proportion: A Case of Two Primaries. In IOP Conference Series: Materials Science and Engineering (Vol. 288, No. 1, p. 012122). IOP Publishing, 2017.

[19] R. Lesh, T. R. Post \& M. Behr. Proportional Reasoning, In H. James ve B. Merlyn (Eds.), Number Concepts and Operations in the Middle Grades, (93-118), 1998.

[20] P. Singh. Understanding the concepts of proportion and ratio constructed by two grades six students, Educational Studies in Mathematics, 43(3), 271-292, 2000.

[21] L. Linchevski \& N. Herscovics. Crossing the cognitive gap between arithmetic and algebra: Operating on the unknown in the context of equations, Educational Studies in Mathematics, 30(1), 39-65, 1996.

[22] A. K. Jitendra, M. R. Harwell, D. N. Dupuis \& S. R. Karl. A randomized trial of the effects of schema-based instruction on proportional problem-solving for students with mathematics problem-solving difficulties, Journal of Learning Disabilities, 50(3), 322-336, 2017.

[23] C. Y. Charalambous \& D. Pitta-Pantazi. Revisiting a theoretical model on fractions: Implications for teaching and research, In Proceedings of the 29 th Conference of the International Group for the Psychology of Mathematics Education (Vol. 2, pp. 233-240), 2005.

[24] R. Siegler, T. Carpenter, F. Fennell, D. Geary, J. Lewis, Y. Okamoto, L. Thompson \& J. Wray. Developing effective fractions instruction for kindergarten through 8th grade: A practice guide (NCEE \#2010-4039), Washington, DC: National Center for Education Evaluation and Regional Assistance, Institute of Education Sciences, U.S. Department of Education, 2010. Online available from http://whatworks.ed.gov/publications/practiceguides 
[25] R. E. Kirk. Experimental design. John Wiley \& Sons, Inc. 1982, Online available from http:/www.corwin.com/sites/default/files/upm-binaries/29 173_Millsap_Chapter_2.pdf

[26] J. R. Fraenkel, N. E. Wallen \& H. H. Hyun. How to Design and Evaluate Research in Education (Eighth Edition), McGraw-Hill, New York, 2012.
[27] Milli Eğitim Bakanlığı. Online available from http://ttkb.meb.gov.tr/www/guncellenen-ogretim-programl ari/icerik/151, 2013.

[28] A. Doğan \& İ. Çetin. Doğru ve ters orantı konusundaki 7. ve 9. Sınıf öğrencilerinin kavram yanılgıları, Uşak Üniversitesi Sosyal Bilimler Dergisi, 2(2), 118-128, 2009. 